\title{
Are You a Functioning Addict?
}

\author{
Skip Stein* \\ COO and Lifestyle Counselor at Whole Foods 4 Healthy Living, USA
}

Submission: May 24, 2017; Published: June 02, 2017

*Corresponding author: Skip Stein, $\mathrm{COO}$ and Lifestyle counselor at Whole Foods 4 Healthy Living, USA, Email: skipstein@wholefoods4healthyliving.com

\section{Opinion}

The functional addict is able to go to work, maintain a family life and appear normal, especially in an addicted society. When everyone is an addict, it is often hard to tell the sick from the well. The most dangerous addiction is the one you do not realize you have and that is the hallmark of the American Food Addict.

We live in a food addicted society. If you eat the Standard American Diet (SAD), you are addicted to fat, salt and sugar. The constant consumption of these unhealthy 'foods' have created the Addicted American Society that consumes foods that most know are unhealthy; yet they just cannot stop. Whether it's a big Mac, a Wendy's Baconator or the double whopper from burger king, these are killing you slowly.

So, you say, I eat healthy and seldom visit these fast food establishments? Well you are probably still consuming a diet rife with fat, salt and sugar. Have you read the label on that box/package of processed food? Read the cereal label that your kids are eating. Because the mandatory labeling requires the highest content item to be listed first, look to see where the sugar is listed! Then look for the fats; there are all sorts of categories that the processors try to obfuscate any true representation. Then examine the stuff you can't even pronounce and have no clue what it is; and you still purchase and consume this product?

The medical institutions in the USA focus on treatment of disease and seldom, if ever, address the cause of heart disease, cancer, diabetes and more. No, they make millions on simply treating the symptoms and ignore the causal factors.

The simple cause of the deadliest diseases afflicting American Society (and much of the Planet) are lousy nutrition and food (loosely termed) consumed. Doctors, those who actually recognize the problem, seldom will tell you or explain the simple solution; no, they prescribe a host of medications and tell you that you have to take them the rest of your life. Prescriptions make other wealthy and, for the most part, make you sicker with the debilitating side effects. Often more prescriptions are provided to offset the side effects of the dangerous (often deadly) prescriptions that were given to treat the initial ailment. Americans are being TREATED TO DEATH!

The really tragic and, I believe, Criminal act is that the doctors who do know better won't advise patients to change their lifestyle and diet because they believe that no one will do it! They suppress this vital information and continue to prescribe dangerous/deadly and, for the most part, unnecessary expensive drugs instead of simply advising a patient to Change Their Lifestyle and diet!

The doctors/physicians and other health industry practitioners who don't know or have no clue about nutrition (that is most of them), they are at fault for their own ignorance as the truth has been out there (but suppressed) for decades. They have been indoctrinated by establishment interests and often corrupt political institutions who are paid (directly or indirectly) by the companies who make/manufacture the crap that has created the American Food Addict.

The answer is so simple that it is ignored or actively suppressed by the healthcare institutions that most Americans have come to trust and rely upon. The complex behemoth health care industry is a mastodon of corruption and monied interests that have no desire to keep Americans healthy. They make too much money treating you to death!

You want the answer? The really Cheap Solution? The Delicious and easy way to regain your health? It is really so simple that most just ignore it. The addiction is not easy to break. Ask any smoker/cigarette, alcoholic, heroin addict or crack head who has beaten their addiction; It isn't that easy! But when you ask those who have beaten it if it was worth it? most will tell you hell yes it was!

If you want to avoid these horrendous lifestyle diseases you must first break your addictions. Some will suggest you take the 'methadone approach' and change addictions and wean yourself off the lousy food. That is called a diet and often fails miserably. 
The most effective and quickest way to benefit from a healthier lifestyle is to just do it. Yep, cold turkey, without the turkey! It will hurt for a few days but gradually your will begin to experience a wondrous feeling of wellbeing as your body begins to finally live and your mind clears and your energy levels soar; often well beyond anything your previously could have imagined and all it takes it eating delicious whole food.
This work is licensed under Creative Commons Attribution 4.0 License

DOI: $10.19080 /$ NFSIJ.2017.03.555602

\section{Your next submission with Juniper Publishers} will reach you the below assets

- Quality Editorial service

- Swift Peer Review

- Reprints availability

- E-prints Service

- Manuscript Podcast for convenient understanding

- Global attainment for your research

- Manuscript accessibility in different formats ( Pdf, E-pub, Full Text, Audio)

- Unceasing customer service

Track the below URL for one-step submission https://juniperpublishers.com/online-submission.php 